Zeitschrift fur Kristallographie 175, 195-202 (1986)

(C) by R. Oldenbourg Verlag, Mūnchen 1986

\title{
Crystal structure of ( $\eta^{5}$-pentamethylcyclopentadienyl) (O,O'-diisopropyldithiophosphato) (dicarbonyl)- iron(II), $\mathrm{FeS}_{2} \mathrm{PO}_{4} \mathrm{C}_{18} \mathrm{H}_{29}$
}

\author{
J. Sanz-Aparicio, S. Martínez-Carrera and S. Garcia-Blanco \\ Dept. Cristalografia, Instituto Rocasolano, Serrano 119, 28006 Madrid, Spain
}

Received: January 10,1986

Crystal structure / $\pi$-bonded aromatic complex / Iron complex / Monodentate dithiophosphate ligand

Abstract. $\mathrm{Mr}=460.36$, monoclinic. $P 2_{1} / c, a=13.718(1), b=11.090(1)$, $c=14.985(1) \AA, \beta=98.162(2)^{\circ}, V=2256.67(9) \AA^{3}, Z=4, D_{x}=1.355$ $\mathrm{Mgm}^{-3}, \mu=0.933 \mathrm{~mm}^{-1}, F(000)=968$, room temperature, final $R=$ $0.047\left(R_{w}=0.048\right)$ for $3184[I \geqslant 3 \sigma(I)]$ observed reflections. The title compound has the "three-legged piano stool" geometry, i.e. the coordination geometry of the iron can be regarded as a distorted octahedron with a $\eta^{\mathbf{5}}-$ $\mathrm{C}_{5} \mathrm{Me}_{5}$ group occupying three coordination sites. Like its nonmethylated analogue it contains an unusually monodentate dithiophosphate ester ligand.

\section{Introduction}

We have previously reported (Sanz-Aparicio, Martinez-Carrera and Garcia-Blanco, 1986) the results of $\mathrm{X}$-ray structural analyses of $\left\{\left(\mathrm{C}_{5} \mathrm{H}_{5}\right)\left[\mathrm{SP}(=\mathrm{S})\left(\mathrm{OPr}^{-}\right)_{2}\right](\mathrm{CO})_{2} \mathrm{Fe}\right\}$ within our studies concerning a series of cyclopentadienyl-Fe(II) derivatives resulting by partial substitution from the dimer of cyclopentadienyl-Fe-tricarbonyl. The present structural resolution of the permethylated-cyclopentadienyl analogue was undertaken in order to obtain a direct comparison between $\mathrm{Cp}\left(\mathrm{C}_{5} \mathrm{H}_{5}\right)$ and $\mathrm{Mp}\left(\mathrm{C}_{5} \mathrm{Me}_{5}\right)$ ligands, with regard to which there is litle information. However, it is well known that the addition of five methyl groups to the $\mathrm{Cp}$ ring provokes changes on the chemistry of the corresponding complexes; for example the complex $\left[\mathrm{MpRhCl}_{2}\right]_{2}$ exists as dimer, while $\left[\mathrm{CpRhCl} \mathrm{C}_{2}\right.$ is an amorphous, 
polymeric reactive complex; or the stability of $\mathrm{Mp}_{2} \mathrm{Fe}$ to hydrogenation as compared to that of the corresponding reaction of $\mathrm{Cp}_{2} \mathrm{Fe}$ under hydroformylation conditions (Teller and Williams, 1980). These chemical differences have to be explained in terms of structural features.

\section{Experimental and determination of the structure}

Recrystallized from ethanol, red prismatic crystals of the title compound were prepared by Morán and Cuadrado (1985) and provided by Prof. J. G. Rodriguez, Facultad de Ciencias, Dept. de Química Orgánica, Univ. Autónoma de Madrid. A crystal of approximate dimensions $0.4 \times 0.4 \times 0.2 \mathrm{~mm}$ was mounted on a glass fiber and used for the determination of the initial cell parameters and subsequent data collection. Accurate cell dimensions were obtained from a least-squares analysis of the settings of 60 reflections with $2^{\circ}<\theta<35^{\circ}$. All measurements were performed on an Enraf Nonius CAD-4 four-circle computer controlled diffractometer with graphite monochromated MoKa radiation. A total of 6582 reflections were measured by the $\omega / 2 \theta$ scan technique, $2^{\circ}<\theta<30^{\circ}$, with 3184 observed reflections $[I \geqslant 3 \sigma(I)]$. Systematic extinctions were $h 0 l, l=2 n$ $+1 ; 0 k 0, k=2 n+1$, thus defining the space group $P 2_{1} / c$. Two standard reflections were monitored periodically during the course of the data collection as a check of crystal stability and they never showed any significant deviation from the initial measurements; $R_{\text {int }}$ value from merging 243 equivalent reflections was 0.022 . In reducing the data Lorentz and polarization factors were applied, but no absorption correction was made.

The structure was solved by interpretation of the Patterson map, which gave the position of the iron atom. The remaining non-C atoms were found by direct methods (MULTAN 80. Main et al., 1980) while C atoms were located in subsequent Fourier syntheses. Atom parameters were refined by full-matrix least-squares procedures with anisotropic temperature factors. Most $H$ atoms could be seen in a difference Fourier synthesis, nine of them located by geometric calculations and all included fixed in the refinement with the isotropic thermal factor of the atoms to which they were attached. Empirical weighting scheme (PESOS, Martínez-Ripoll and Cano, 1975) as to give no trends in $\langle w \Delta F\rangle v s .\left\langle F_{\mathrm{o}}\right\rangle$ and $\langle\sin \theta \mid \lambda\rangle$; final refinement gave $R=0.047\left(R_{w}=0.048\right)$, maximum and average shift/error ratios were 0.052 and $0.0043(S=0.79)$. A final difference Fourier synthesis did not show any peak higher than 0.56 or lower than $-1.2 \mathrm{e} \AA^{-3}$. Atomic scattering factors and anomalous dispersion corrections were taken from the International Tables for X-Ray Crystallography (1974). Most calculations and drawings were performed with the X-RAY SYSTEM (Stewart, Kundell and Baldwin, 1976) and PARST (Nardelli, 1983), on a Vax 11/750 computer. 
Table 1. Atomic parameters for $\mathrm{FeS}_{2} \mathrm{PO}_{4} \mathrm{C}_{18} \mathrm{H}_{29}$. Coordinates and thermal parameters as $U_{\text {eq }}=\frac{1}{3} \sum_{i j} U_{i j} a_{i}^{*} a_{j}^{*} a_{i} a_{j} \cos \left(a_{i}, a_{j}\right) \cdot 10^{4}$

\begin{tabular}{lllrr}
\hline Atom & $x$ & $y$ & \multicolumn{1}{l}{$z$} & \multicolumn{1}{l}{$U_{\text {eq }}$} \\
\hline Fe & $0.6882(4)$ & $0.22159(5)$ & $0.10202(4)$ & $323(2)$ \\
P & $0.77448(7)$ & $0.51618(9)$ & $0.17626(7)$ & $322(3)$ \\
S1 & $0.65215(7)$ & $0.41438(9)$ & $0.14557(7)$ & $383(3)$ \\
S2 & $0.74549(9)$ & $0.67105(10)$ & $0.22667(9)$ & $507(4)$ \\
O3 & $0.84953(21)$ & $0.43417(27)$ & $0.23931(20)$ & $430(9)$ \\
O4 & $0.83238(21)$ & $0.52618(26)$ & $0.09195(19)$ & $409(9)$ \\
O2 & $0.80594(35)$ & $0.15918(39)$ & $0.27281(28)$ & $872(17)$ \\
O1 & $0.86391(29)$ & $0.26580(40)$ & $0.01881(32)$ & $829(17)$ \\
C1 & $0.79559(33)$ & $0.25612(39)$ & $0.05254(32)$ & $468(15)$ \\
C2 & $0.76025(37)$ & $0.18763(40)$ & $0.20691(33)$ & $520(16)$ \\
C3 & $0.95039(33)$ & $0.47506(47)$ & $0.27023(34)$ & $538(16)$ \\
C4 & $0.80652(40)$ & $0.61358(43)$ & $0.01916(32)$ & $552(17)$ \\
C9 & $0.55979(32)$ & $0.21527(44)$ & $0.00596(31)$ & $491(14)$ \\
C10 & $0.62953(35)$ & $0.13415(49)$ & $-0.01844(30)$ & $518(16)$ \\
C11 & $0.65352(38)$ & $0.05066(42)$ & $0.05053(39)$ & $581(18)$ \\
C12 & $0.59648(45)$ & $0.07349(54)$ & $0.11726(35)$ & $663(20)$ \\
C13 & $0.53892(35)$ & $0.17583(55)$ & $0.09317(36)$ & $615(19)$ \\
C14 & $0.51073(57)$ & $0.31906(64)$ & $-0.04629(58)$ & $1057(30)$ \\
C7 & $0.77054(62)$ & $0.54751(75)$ & $-0.06495(41)$ & $950(29)$ \\
C5 & $1.01748(44)$ & $0.38222(87)$ & $0.24055(49)$ & $970(31)$ \\
C6 & $0.96110(47)$ & $0.49048(80)$ & $0.37043(43)$ & $936(28)$ \\
C18 & $0.46236(51)$ & $0.23203(96)$ & $0.14406(67)$ & $1336(42)$ \\
C8 & $0.89648(70)$ & $0.68514(76)$ & $0.01221(52)$ & $1123(36)$ \\
C17 & $0.59291(81)$ & $-0.00320(95)$ & $0.20026(52)$ & $1447(45)$ \\
C15 & $0.66681(56)$ & $0.13764(97)$ & $-0.10876(45)$ & $1138(36)$ \\
C16 & $0.72307(62)$ & $-0.05434(60)$ & $0.04425(78)$ & $1260(40)$ \\
\hline & & & &
\end{tabular}

Final atomic coordinates and equivalent values $\left(U_{e q}\right)$ of the anisotropic thermal parameters are given in Table 1, while bond distances and bond angles are listed in Table 2.

\section{Discussion}

Figure 1 a shows a view of the molecule giving the numbering system we have used and in Figure $1 \mathrm{~b}$ a portion of it is projected onto the carbocyclic ring ${ }^{2}$.

The ring carbon atoms of the Mp system have a mean deviation of $0.01 \AA$ from their least-squares plane (see Table 3). The iron atom lies $1.731 \AA$ to one side of this plane; the carbon atoms of the methyl sub-

1 Additional material to this paper can be ordered from the Fachinformationszentrum Energie-Physik-Mathematik, D-7514 Eggenstein-Leopoldshafen 2, FRG. Please quote reference no. CSD 51 344, the names of the authors and the title of the paper 
Table 2. Bond lengths $(\AA)$ and angles $\left({ }^{\circ}\right)$, with e.s.d.'s in parentheses

\begin{tabular}{|c|c|c|c|}
\hline $\begin{array}{l}\mathrm{Fe}-\mathrm{Cp} \\
\mathrm{Fe}-\mathrm{S} 1 \\
\mathrm{Fe}-\mathrm{C} 1 \\
\mathrm{Fe}-\mathrm{C} 2 \\
\mathrm{Fe}-\mathrm{C} 9 \\
\mathrm{Fe}-\mathrm{C} 10 \\
\mathrm{Fe}-\mathrm{C} 11 \\
\mathrm{Fe}-\mathrm{C} 12 \\
\mathrm{Fe}-\mathrm{C} 13 \\
\mathrm{P}-\mathrm{S} 1 \\
\mathrm{P}-\mathrm{S} 2 \\
\mathrm{P}-\mathrm{O} \\
\mathrm{P}-\mathrm{O} \\
\mathrm{O} 3-\mathrm{C} 3 \\
\mathrm{O} 4-\mathrm{C} 4 \\
\mathrm{O} 2-\mathrm{C} 2 \\
\mathrm{O} 1-\mathrm{C} 1 \\
\mathrm{C} 3-\mathrm{C} 5 \\
\mathrm{C} 3-\mathrm{C} 6 \\
\mathrm{C} 4-\mathrm{C} 7 \\
\mathrm{C} 4-\mathrm{C} 8 \\
\mathrm{C} 9-\mathrm{C} 10 \\
\mathrm{C} 9-\mathrm{C} 13 \\
\mathrm{C} 9-\mathrm{C} 14 \\
\mathrm{C} 10-\mathrm{C} 11 \\
\mathrm{C} 10-\mathrm{C} 15 \\
\mathrm{C} 11-\mathrm{C} 12 \\
\mathrm{C} 11-\mathrm{C} 16 \\
\mathrm{C} 12-\mathrm{C} 13 \\
\mathrm{C} 12-\mathrm{C} 17 \\
\mathrm{C} 13-\mathrm{C} 18\end{array}$ & $\begin{array}{l}1.727(1) \\
2.311(1) \\
1.775(5) \\
1.771(5) \\
2.118(4) \\
2.108(5) \\
2.078(5) \\
2.106(6) \\
2.104(5) \\
2.021(1) \\
1.940(1) \\
1.582(3) \\
1.589(3) \\
1.467(5) \\
1.465(5) \\
1.137(6) \\
1.131(7) \\
1.490(10) \\
1.498(8) \\
1.481(8) \\
1.483(11) \\
1.399(7) \\
1.445(7) \\
1.497(9) \\
1.392(7) \\
1.514(9) \\
1.378(8) \\
1.517(9) \\
1.400(8) \\
1.513(10) \\
1.517(11)\end{array}$ & $\begin{array}{l}\mathrm{C} 1-\mathrm{Fe}-\mathrm{Cp} \\
\mathrm{C} 2-\mathrm{Fe}-\mathrm{Cp} \\
\mathrm{S} 1-\mathrm{Fe}-\mathrm{Cp} \\
\mathrm{C} 1-\mathrm{Fe}-\mathrm{C} 2 \\
\mathrm{~S} 1-\mathrm{Fe}-\mathrm{C} 2 \\
\mathrm{~S} 1-\mathrm{Fe}-\mathrm{C} 1 \\
\mathrm{O} 3-\mathrm{P}-\mathrm{O} 4 \\
\mathrm{~S} 2-\mathrm{P}-\mathrm{O} 4 \\
\mathrm{~S} 2-\mathrm{P}-\mathrm{O} 3 \\
\mathrm{~S} 1-\mathrm{P}-\mathrm{O} 4 \\
\mathrm{~S} 1-\mathrm{P}-\mathrm{O} 3 \\
\mathrm{~S} 1-\mathrm{P}-\mathrm{S} 2 \\
\mathrm{Fe}-\mathrm{S} 1-\mathrm{P} \\
\mathrm{P}-\mathrm{O}-\mathrm{C} 3 \\
\mathrm{P}-\mathrm{O} 4-\mathrm{C} 4 \\
\mathrm{Fe}-\mathrm{C} 1-\mathrm{O} 1 \\
\mathrm{Fe}-\mathrm{C} 2-\mathrm{O} 2 \\
\mathrm{O} 3-\mathrm{C} 3-\mathrm{C} 6 \\
\mathrm{O} 3-\mathrm{C} 3-\mathrm{C} 5 \\
\mathrm{C} 5-\mathrm{C} 3-\mathrm{C} 6 \\
\mathrm{O}-\mathrm{C} 4-\mathrm{C} 8 \\
\text { O4-C4-C7 } \\
\mathrm{C} 7-\mathrm{C} 4-\mathrm{C} 8 \\
\mathrm{C} 13-\mathrm{C} 9-\mathrm{C} 14 \\
\mathrm{C} 10-\mathrm{C} 9-\mathrm{C} 14 \\
\mathrm{C} 10-\mathrm{C} 9-\mathrm{C} 13 \\
\mathrm{C} 9-\mathrm{C} 10-\mathrm{C} 15 \\
\mathrm{C} 9-\mathrm{C} 10-\mathrm{C} 11 \\
\mathrm{C} 11-\mathrm{C} 10-\mathrm{C} 15 \\
\mathrm{C} 10-\mathrm{C} 11-\mathrm{C} 16 \\
\mathrm{C} 10-\mathrm{C} 11-\mathrm{C} 12 \\
\mathrm{C} 12-\mathrm{C} 11-\mathrm{C} 16 \\
\mathrm{C} 11-\mathrm{C} 12-\mathrm{C} 17 \\
\mathrm{C} 11-\mathrm{C} 12-\mathrm{C} 13 \\
\mathrm{C} 13-\mathrm{C} 12-\mathrm{C} 17 \\
\mathrm{C} 9-\mathrm{C} 13-\mathrm{C} 12 \\
\mathrm{C} 12-\mathrm{C} 13-\mathrm{C} 18 \\
\mathrm{C} 9-\mathrm{C} 13-\mathrm{C} 18\end{array}$ & $\begin{array}{r}122.5(1) \\
123.7(1) \\
119.7(0) \\
91.8(2) \\
93.5(2) \\
98.3(1) \\
99.1(2) \\
113.6(1) \\
115.4(1) \\
110.5(1) \\
105.3(1) \\
111.9(1) \\
112.0(1) \\
121.0(3) \\
122.9(3) \\
172.9(4) \\
176.1(4) \\
107.8(4) \\
106.7(5) \\
113.7(5) \\
106.9(5) \\
108.8(4) \\
112.6(5) \\
125.0(5) \\
129.1(5) \\
105.8(4) \\
123.2(5) \\
109.4(4) \\
127.3(5) \\
123.3(6) \\
108.5(5) \\
127.8(6) \\
125.5(6) \\
108.6(5) \\
125.8(6) \\
107.6(4) \\
127.5(6) \\
124.8(5)\end{array}$ \\
\hline
\end{tabular}

- $\mathrm{Cp}$ is the centre of the ring

stituents each lie to the opposite side of the ring; they are bent away from the plane by a mean value of $0.08 \AA$. The different distortions possibly reflect steric interaction between adjacent methyl groups. As in other Mp complexes, one hydrogen atom of each methyl group is exo to the metal atom (Teller and Williams, 1980; Churchill and $\mathrm{Ni}, 1973$ ).

The average $C$ (ring) $-C$ (ring) bond length is shorter in the Cp complex (Table 4) what may be attributed to thermal vibration and libration leading to an apparent shortening. This will also affect the $\mathrm{Fe}-\mathrm{C}$ distances, but 


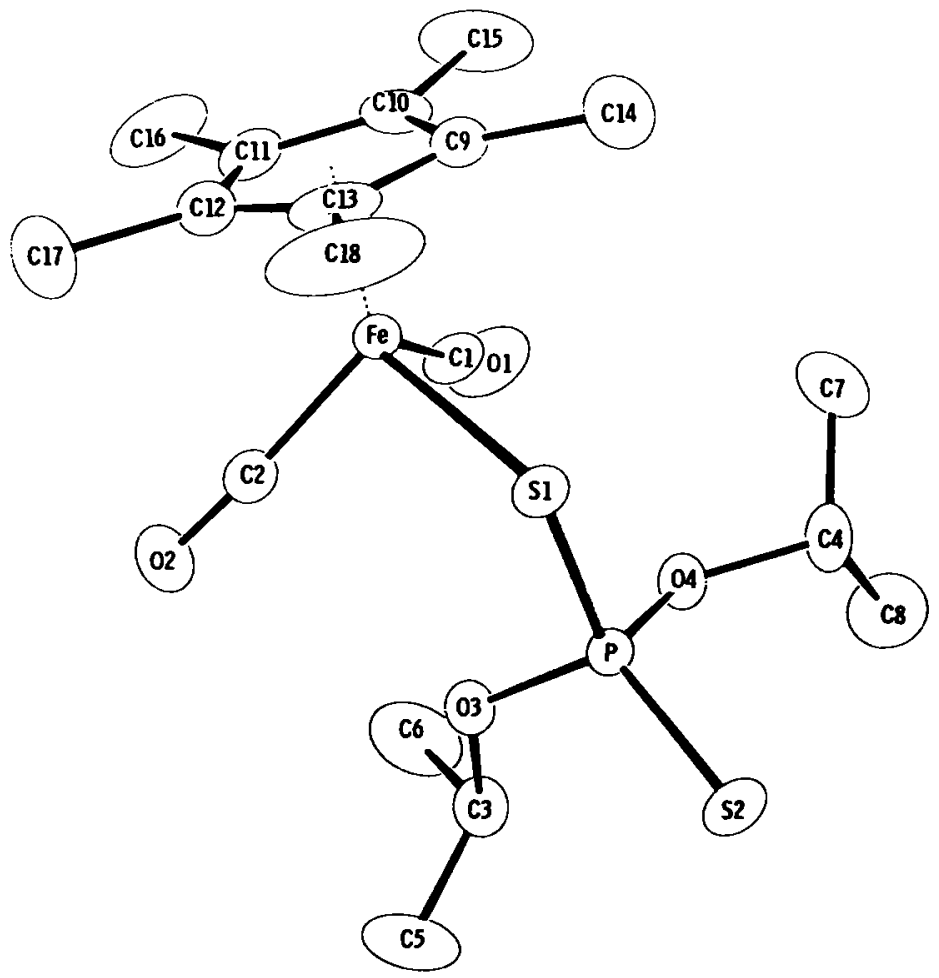

Fig. 1(a). General view of the molecule showing the atomic numbering. Hydrogens omitted for clarity

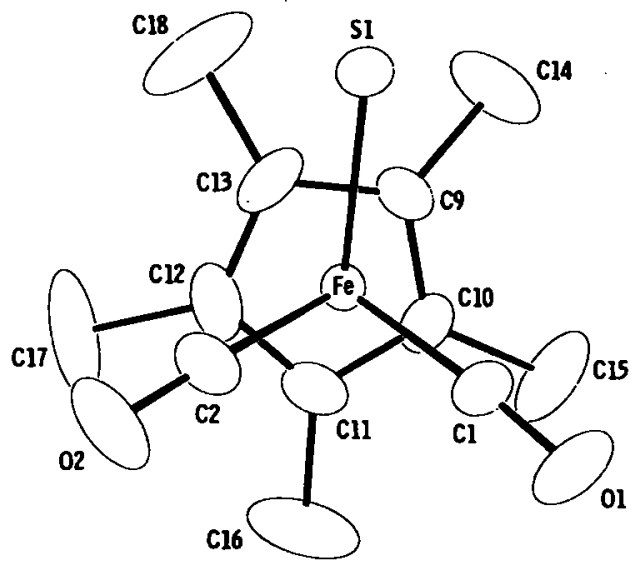

Fig. 1(b). Projection of iron environs onto the cyclopentadienyl plane 
Table 3. Least squares plane in the $\pi-\mathrm{C}_{5}\left(\mathrm{CH}_{3}\right)_{5}$ group ${ }^{2, b}$

\begin{tabular}{lrrr}
\hline-0.671 & $X-0.593$ & $Y-0.444$ & $Z+6.597=0$ \\
\hline C9* & -0.005 & $C 14$ & 0.034 \\
C10* & 0.012 & $C 15$ & 0.112 \\
C11* & -0.015 & C16 & 0.067 \\
C12* & 0.015 & C17 & 0.124 \\
C13* & -0.003 & C18 & 0.069 \\
Fe & -1.731 & & \\
\hline
\end{tabular}

- Planes are defined in cartesian coordinates $(X, Y, Z)$ which are related to the monoclinic fractional cell coordinates $(x, y, z)$ by the transformation $X=x a+z c \cos \beta$, $Y=y b$ and $Z=z c \sin \beta$.

- Planes are calculated using unit weights for all atoms marked with an asterisk

Table 4. Comparative distances $(\AA)$

\begin{tabular}{lll}
\hline Compound reference & $\begin{array}{l}\mathrm{CP}[\mathrm{SP}(=\mathrm{S}) \\
\left.(\mathrm{OPr})_{2}\right](\mathrm{CO})_{2} \mathrm{Fe}\end{array}$ & $\begin{array}{l}\mathrm{Mp}\left[\mathrm{SP}(=\mathrm{S})(\mathrm{OPH})_{2}\right](\mathrm{CO})_{2} \mathrm{Fe} \\
\text { this work }\end{array}$ \\
\hline (a) & $2.085(7)$ & $2.103(5)$ \\
$\mathrm{Fe}-\mathrm{C}$ ring (av) & $1.721(1)$ & $1.731(1)$ \\
$\mathrm{Fe}-$ ring plane & $1.786(5)$ & $1.773(5)$ \\
$\mathrm{Fe}-\mathrm{CO}$ (av) & $2.322(2)$ & $2.311(1)$ \\
$\mathrm{Fe}-\mathrm{S} 1$ & $1.383(11)$ & $1.403(8)$ \\
$\mathrm{C}$ ring-C ring & & \\
\hline
\end{tabular}

(a) Sanz et al. (1986)

not the Fe-ring plane distance. It would be expected some influence due to methyl groups in the interatomic distances of the remainder of the molecule, as was found in the shorter $\mathrm{Ti}-\mathrm{Cl}$ distance of the $\left(\eta^{5}-\mathrm{C}_{5} \mathrm{Me}_{4} \mathrm{Et}\right) \mathrm{TiCl}_{3}$ complex (Alcock, Toogood and Wallbridge, 1984). This can be explained in terms of the inductive electron donation by the alkyl groups and is in agreement with the suggestion of enhanced electron-releasing ability of a peralkylated $\mathrm{C}_{5} \mathrm{R}_{5}$ group based on chemical reactivity, which could increase the electron density on the metal atom, thereby altering metal-other ligands distances. In fact, this effect is not observed and the $\mathrm{Fe}-\mathrm{CO}, \mathrm{C}-\mathrm{O}$ and $\mathrm{Fe}-\mathrm{S} 1$ distances are identical within limits of error to those found in the non-methylated analogue (Table 4).

The geometry of the dithiophosphate ester ligand is the same as in the Cp complex (Sanz-Aparicio et al., 1986, and references therein) i.e., the phosphorus atom sits in a roughly tetrahedral environment, with both $\mathrm{P}-\mathrm{S}$ distances showing some multiple bonding contribution. As it happened there, this is one of the very few structures where this ligand is 


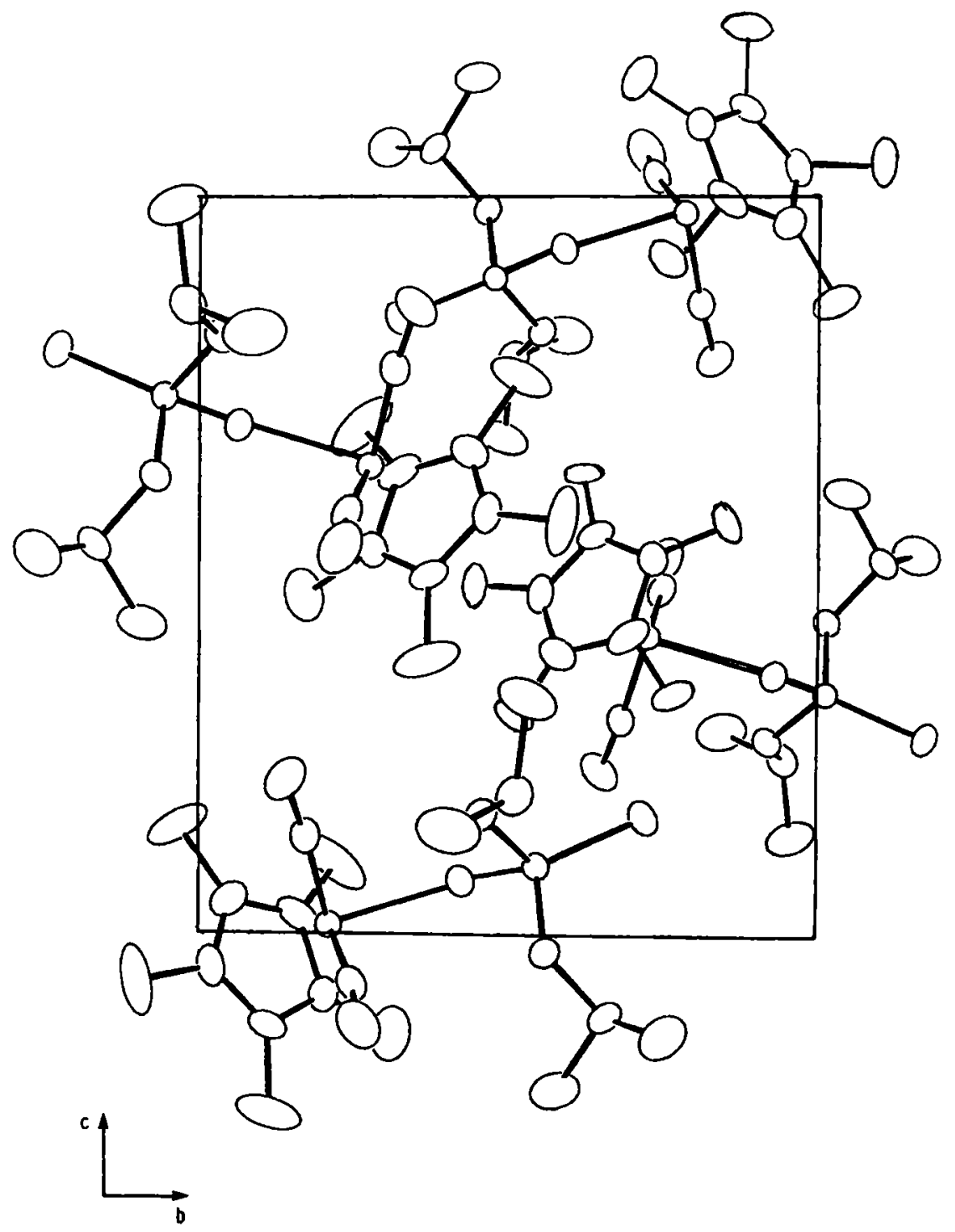

Fig. 2. Packing in the unit cell, (100) projection

monodentate (Molloy, Hossain, van der Helm, Zuckerman and Haiduc, 1979).

The packing of molecules in the crystal, (100) projection, is shown in Figure 2. It contains no significant short intermolecular distances and it is built only by Van der Waals forces. 


\section{References}

Alcock, N. W., Toogood, G. E., Wallbridge, M. G. H.: Electronic structural effects in the structure of trichloro $\left(\eta^{3}\right.$-ethyltetramethylcyclopentadienyl)titanium(IV), $\mathrm{Ti}\left(\mathrm{C}_{11} \mathrm{H}_{17}\right) \mathrm{Cl}_{3}$. Acta Crystallogr. C40, 598-600 (1984)

Churchill, M. R., Ni, S. W. Y.: Crystal structure and location of the bridging hydride ligand in $\mu$-chloro- $\theta$-hydrido-bis\{chloro- (pentamethylcychopentadienyl) rhodium (III)], a homogeneous hydrogenation catalyst. J. Am. Chem. Soc. 95, 2150-2155 (1973)

International Tables for X-Ray Crystallography, Vol. 4. Birmingham: Kynoch Press (1974) Main, P., Fiske, S. J., Hull, S. E., Lessinger, L., Germain, G., Declerck, J. P., Woolfson, M. H.: MULTAN 80. A system of computer programs for automatic solution of crystal structures from X-ray diffraction data. Univ. of York, England and Louvain, Belgium (1980)

Martínez-Ripoll, M., Cano, F. H.: PESOS. A computer program for the automatic treatment of weighting schemes. Instituto Rocasolano, CSIC. Madrid, Spain (1975)

Molloy, K. C., Hossain, M. B., Van der Helm, D., Zuckerman, J. J., Haiduc, I.: Crystal and molecular structure of $\left(0,0^{\prime}\right.$-diethyldithiophosphato)triphenyltin(IV) at $138 \mathrm{~K}$. A unique monodentate dithiophosphate derivative. Inorg. Chem. 18, 12, 3507-3511 (1979)

Morán, M., Cuadrado, I.: Preparation of the monodentate dithiophosphate complexes $\mathrm{Cp} * \mathrm{Fe}(\mathrm{Co})_{2}\left(\eta^{\prime}-\mathrm{SP}(\mathrm{S})(\mathrm{OR})_{2}\right)$. J. Organomet. Chem. 295, 353-363 (1985)

Nardelli, M.: PARST. Computer and Chemistry, 7, 95-98. Italy (1983)

Sanz-Aparicio, J., Martínez-Carrera, S., Garcia-Blanco, S.: Crystal structure of ( $\eta^{3}$-cyclopentadienyl) $\left(0,0^{\prime}\right.$-diisopropyldithiophosphato)(dicarbonyl)iron(II). Acta Crystallogr. (1986) (to be published)

Stewart, J. M., Kundell, F. A., Baldwin, J. C.: The X-RAY SYSTEM. Computer Science Center, University of Maryland, USA (1976)

Teller, R. G., Williams, J. M.: Crystal and molecular structure of bis[dicarbonyl( $\pi$ pentamethylcyclopentadienyl)iron], $\left(\eta^{5}-\mathrm{C}_{5} \mathrm{Me}_{5}\right)_{2} \mathrm{Fe}_{2}(\mathrm{CO})_{4}$, and structural comparison with the nonmethylated analogue. Inorg. Chem. 19, 2770-2773 (1980) 